Article

\title{
Balticolid: A New 12-Membered Macrolide with Antiviral Activity from an Ascomycetous Fungus of Marine Origin
}

\section{Muftah A. M. Shushni ${ }^{1{ }^{*},}$, Rajinder Singh ${ }^{1}$, Renate Mentel $^{2}$ and Ulrike Lindequist ${ }^{3}$}

1 Department of Pharmacognosy, Faculty of Pharmacy, Garyounis University, P.O. Box 5341, Benghazi, Libya; E-Mail: dr.rajindersingh@yahoo.com (R.S.)

2 Institute of Pharmacy, Ernst-Moritz-Arndt-University, Friedrich-Ludwig-Jahn-Strasse 17, D-17487 Greifswald, Germany; E-Mail: renate.mentel@uni-greifswald.de (R.M.)

3 Friedrich-Loffler-Institute of Medical Microbiology, Ernst-Moritz-Arndt-University, Martin-Luther-Strasse 6, D-17487 Greifswald, Germany;

E-Mail: lindequi@uni-greifswald.de (U.L.)

* Author to whom correspondence should be addressed; E-Mail: muftah.shushni@ yahoo.com; Tel.: +218-91-7270074; Fax: +218-61-2231520.

Received: 19 March 2011; in revised form: 27 April 2011 / Accepted: 10 May 2011 / Published: 13 May 2011

\begin{abstract}
A new 12-membered macrolide, balticolid (1) was isolated from the EtOAc extract of the culture broth of fungal strain 222 belonging to the Ascomycota, which was found on driftwood collected from the coast of the Greifswalder Bodden, Baltic Sea, Germany. The structure of balticolid was determined to be $(3 R, 11 R)$, (4E,8E)-3-hydroxy-11-methyloxacyclododeca-4,8-diene-1,7-dione using extensive spectral data as well as the modified Mosher ester method. Balticolid (1) displayed anti-HSV-1 activity with an $\mathrm{IC}_{50}$ value of $0.45 \mu \mathrm{M}$.
\end{abstract}

Keywords: balticolid; antiviral; herpes simplex virus; marine fungi

\section{Introduction}

Marine microorganisms are recognized as important sources of pharmacologically active metabolites [1-3]. In particular, a growing number of marine-derived fungi have been reported to produce novel bioactive secondary metabolites. In an earlier part of this chemical investigation we described the isolation and structure elucidation of several new antiviral naphthalenone derivatives from the EtOAc extract of an ascomycetous fungus [4]. On further investigation of this fungus, we 
describe herein the isolation, structure elucidation and the biological activity of the novel 12-membered macrolide, balticolid (1).

Fungal metabolites that contain twelve-membered lactone rings like recifeiolide from Cephalosporium recifei [5], cladospolides A-C from Cladosporium cladosporioides [6] and Cladosporium tenuissimum [7], patulolides A-C from Penicillium urticae [8,9], pandangolides 1-4 from Cladosporium herbarum [10] and chloriolide from Chloridium virescens var. chlamydosporum [11] have already been reported.

\section{Results and Discussion}

Balticolid (1) was obtained as colorless oil. Its molecular formula was determined to be $\mathrm{C}_{12} \mathrm{H}_{16} \mathrm{O}_{4}$ by ESIMS at $m / z 225[\mathrm{M}+\mathrm{H}]^{+}$and by HRESIMS at $m / z, 471.2001$ for $\mathrm{C}_{24} \mathrm{H}_{32} \mathrm{O}_{8} \mathrm{Na}$ as $[2 \mathrm{M}+\mathrm{Na}]^{+}$, suggesting the existence of five degrees of unsaturation. The UV spectrum showed absorption bands consistent with a conjugated carbonyl group. Inspection of the ${ }^{1} \mathrm{H}$ and ${ }^{13} \mathrm{C}$ NMR data (Table 1) together with DEPT and HMQC spectral data revealed the presence of one methyl, three methylenes, six methines (four olefinic) and two quaternary carbons (carbonylic).

In addition, the IR spectrum showed the presence of a hydroxyl group $\left(3435 \mathrm{~cm}^{-1}\right)$ and trans disubstituted alkenes $\left(1662 \mathrm{~cm}^{-1}\right)$. An absorption band appeared at $1716 \mathrm{~cm}^{-1}$, and is due to the conjugated ketone, the absorption band of the 12-membered lactone potentially merged with the aforementioned as a single absorption band. The ${ }^{1} \mathrm{H}$ NMR splitting pattern of $\mathbf{1}$ showed coupling between the protons at $\delta_{\mathrm{H}} 1.34$ and 5.11 which indicates the presence of a $\mathrm{CH}_{3}-\mathrm{CH}-\mathrm{O}$ group. The ${ }^{1} \mathrm{H}-{ }^{1} \mathrm{H}$ COSY and ROESY spectra revealed two structural elements, one of C-2 to C-6 and the second from the unsaturated methine carbon $\mathrm{C}-8$ to methyl group $\mathrm{C}-12$. HMBC correlations observed from methylene protons $\mathrm{H}_{2}-2\left(\delta_{\mathrm{H}} 2.68,2.62\right)$ and deshielded oxymethine proton $\mathrm{H}-11\left(\delta_{\mathrm{H}} 5.11\right)$ to carboxy carbon $\mathrm{C}-1$ established the location of the ester linkage (Table 1). The HMBC correlation of H-3 $\left(\delta_{\mathrm{H}} 4.54\right)$ with C-1, C-2 together with molecular formula $\mathrm{C}_{12} \mathrm{H}_{16} \mathrm{O}_{4}$ indicated the presence of a methine group and a hydroxyl group at $\mathrm{C}-3$. The presence of a methyl group at $\mathrm{C}-11$ was deduced by the HMBC correlation of $\mathrm{H}_{3}-12\left(\delta_{\mathrm{H}} 1.34\right)$ with $\mathrm{C}-9\left(\delta_{\mathrm{C}} 148.1\right), \mathrm{C}-10\left(\delta_{\mathrm{C}} 39.6\right)$ and $\mathrm{C}-11\left(\delta_{\mathrm{C}} 72.1\right)$. The geometries of $\mathrm{C} 4-\mathrm{C} 5$ and $\mathrm{C} 8-\mathrm{C} 9$ double bonds were assigned $E, E$ on the basis of ${ }^{1} \mathrm{H}-{ }^{1} \mathrm{H}$ coupling constants $\left(J_{\mathrm{H} 4-\mathrm{H} 5}=15.9 \mathrm{~Hz}, J_{\mathrm{H} 8-\mathrm{H} 9}=16.1 \mathrm{~Hz}\right.$ respectively) leading to the gross structure of $\mathbf{1}$ as shown (Figure 1). Therefore, compound 1 was established as (4E,8E)-3-hydroxy-11-methyloxacyclododeca4,8-diene-1,7-dione and named as balticolid.

The orientation of hydroxyl group at C-3 $\left(\delta_{\mathrm{H}} 69.1\right)$ was assigned by taking into account the ${ }^{1} \mathrm{H}-{ }^{1} \mathrm{H}$ coupling constant values of $\mathrm{H}-3\left(\delta_{\mathrm{H}} 1.34\right)$ with all the neighboring protons $\left(J_{\mathrm{H} 2 \mathrm{a}-\mathrm{H} 3}=3.4 \mathrm{~Hz}\right.$, $J_{\mathrm{H} 2 \mathrm{~b}-\mathrm{H} 3}=4.7 \mathrm{~Hz}, J_{\mathrm{H} 3-\mathrm{H} 4}=2.8 \mathrm{~Hz}$ ). On the basis of vicinal coupling constant values for other protons a 3D structure for $\mathbf{1}$ was constructed as shown in Figure 2. These findings were also supported by cross peaks in ROESY spectrum and difference NOEs experiments.

Furthermore, the absolute configuration of balticolid (1) at C-3 was deduced by modified high-field ${ }^{1} \mathrm{H}$ NMR Mosher method [12-14]. In order to determine the absolute configuration at C-3, balticolid (1) was treated with $(R)$ and $(S)$ - $\alpha$-methoxy- $\alpha$-trifluoromethyl-phenylacetyl chloride (MTPA-Cl) in the presence of 4-dimethylaminopyridine (DMAP) and dicyclohexylcarbodiimide to give the $(S)$-and $(R)$-MTPA esters respectively. In the ${ }^{1} \mathrm{H}$ NMR spectrum of the $(S)$-MTPA ester, the proton signals 
assigned to $\mathrm{H}-2 \mathrm{a}$, and $\mathrm{H}-2 \mathrm{~b}$ were observed at a higher field than those of the $(R)$-MTPA ester, and $\mathrm{H}-4$, $\mathrm{H}-5, \mathrm{H}-6 \mathrm{a}$ and H-6b were observed at a lower field than those of the $(R)$-MTPA ester. The bulk effect on chemical shifts induced by esterification with the chiral reagents was calculated using $\Delta \delta=\left(\delta_{S}-\delta_{R}\right)$, where $\delta_{S}$ and $\delta_{R}$ are the shifts (in ppm) of diagnostic protons neighboring the chiral center in balticolid (1) of the $(S)$ and $(R)$ Mosher's esters respectively. The absolute configuration of 1 was obtained by positioning the protons with positive $\Delta \delta$ values on the right side and those with negative $\Delta \delta$ values on the left side in the model described by Ohtani et al. [13] which clearly showed that the absolute configuration at $\mathrm{C}-3$ was $R$ (Figure 3 ).

The relative configuration of $\mathbf{1}$ at $\mathrm{C}-11$ was elucidated from the interactions observed in difference NOEs experiments. By applying a decoupling field to methine proton $\mathrm{H}-8\left(\delta_{\mathrm{H}} 5.99\right)$ there was enhancement of H-5 $\left(\delta_{\mathrm{H}} 5.75\right), \mathrm{H}-6 \mathrm{a}\left(\delta_{\mathrm{H}} 3.43\right)$ and $\mathrm{H}-10 \mathrm{a}\left(\delta_{\mathrm{H}} 2.52\right)$ indicating that these protons are situated on the same face while H-6b is on the opposite face. Furthermore, enhancement of proton H-4 $\left(\delta_{\mathrm{H}} 5.73\right)$ and $\mathrm{H}-11\left(\delta_{\mathrm{H}} 5.11\right)$ upon irradiation of $\mathrm{H}-2 \mathrm{~b}\left(\delta_{\mathrm{H}} 2.68\right)$ and $\mathrm{H}-9\left(\delta_{\mathrm{H}} 6.78\right)$ were observed respectively (Figure 2) indicating that these protons are situated on the opposite face or $\beta$-oriented in 1. Therefore, the absolute configurations of both chiral centers of $\mathbf{1}$ were assigned as $3 R, 11 R$.

Table 1. ${ }^{1} \mathrm{H}\left[\mathrm{CD}_{3} \mathrm{OD}, 600 \mathrm{MHz}\right]$ and ${ }^{13} \mathrm{C} \mathrm{NMR}\left[\mathrm{CD}_{3} \mathrm{OD}, 150 \mathrm{MHz}\right]$ spectral data for compound $\mathbf{1}^{\mathrm{a}}$.

\begin{tabular}{|c|c|c|c|c|c|}
\hline Position & $\delta_{\mathrm{H}}^{\mathbf{b}}$ & ${ }^{1} \mathrm{H}-{ }^{1} \mathrm{H} \mathrm{COSY}$ & ROESY & $\delta_{\mathrm{C}}^{\mathrm{c}}$ & HMBC $(\mathrm{H} \rightarrow \mathrm{C})$ \\
\hline 1 & - & - & - & $172.0(\mathrm{~s})$ & - \\
\hline \multirow[t]{2}{*}{2} & $2.62(1 \mathrm{H}, \mathrm{dd}, 13.4,3.4 \mathrm{Ha})$ & $2 b, 3$ & - & \multirow{2}{*}{$43.3(t)$} & $1,3,4$ \\
\hline & $2.68(1 \mathrm{H}, \mathrm{dd}, 13.4,4.7 \mathrm{Hb})$ & $2 \mathrm{a}, 3$ & $5 / 4,11$ & & $1,3,4,5$ \\
\hline 3 & $4.54(1 \mathrm{H}, \mathrm{m})$ & $4,2 \mathrm{a} / \mathrm{b}(6 \mathrm{a})$ & $6 a / 6 b$ & 69.1(d) & 1,2 \\
\hline 4 & $5.73(1 \mathrm{H}, \mathrm{dd}, 15.9,2.8)$ & 5,3 & $9,2 \mathrm{a} / 2 \mathrm{~b}$ & $138.4(d)$ & $3,5,6$ \\
\hline 5 & $5.75(1 \mathrm{H}, \mathrm{m})$ & $4,6 \mathrm{a} / \mathrm{b}$ & $2 \mathrm{a} / 2 \mathrm{~b}$ & $125.2(d)$ & $3,4,6,7$ \\
\hline \multirow[t]{2}{*}{6} & $3.43(1 \mathrm{H}, \mathrm{br} \mathrm{dd}, 13.6,6.8, \mathrm{Ha})$ & $6 b, 5,3$ & 8 & \multirow{2}{*}{$45.8(\mathrm{t})$} & $4,5,7,8$ \\
\hline & $3.22(1 \mathrm{H}, \mathrm{ddd} 13.6,4.5,1.7, \mathrm{Hb})$ & $6 a, 5$ & 9,3 & & $4,5,7$ \\
\hline 7 & - & - & - & $202.7(\mathrm{~s})$ & - \\
\hline 8 & $5.99(1 \mathrm{H}$, br d, 16.1$)$ & $9,10 \mathrm{a} / \mathrm{b}$ & $10 \mathrm{a} / 10 \mathrm{~b}$ & $132.8(d)$ & $6,7,9,10,11$ \\
\hline 9 & $6.78(1 \mathrm{H}, \mathrm{ddd}, 16.1,8.9,6.6)$ & $8,10 \mathrm{a} / \mathrm{b}$ & $6 \mathrm{~b} / 6 \mathrm{a}, 5 / 4,11,10 \mathrm{~b} / 10 \mathrm{a}$ & $148.1(\mathrm{~d})$ & $8,10,11$ \\
\hline \multirow[t]{2}{*}{10} & $2.52(1 \mathrm{H}, \mathrm{dddd}, 13.4,6.6,3.3,1.3, \mathrm{Ha})$ & 10b, $9,11(8)$ & 8,11 & \multirow{2}{*}{$39.6(\mathrm{t})$} & $8,9,11$ \\
\hline & $2.38(1 \mathrm{H}, \mathrm{ddd}, 13.4,11.0,8.9, \mathrm{Hb})$ & $10 \mathrm{a}, 9,11,(8)$ & 8,11 & & $8,9,11,12$ \\
\hline 11 & $5.11(1 \mathrm{H}, \mathrm{ddq}, 11.0,3.3,6.3)$ & $10 \mathrm{a} / \mathrm{b}, 12$ & $10 \mathrm{~b} / 10 \mathrm{a}, 9$ & 72.1 (d) & $1,9,10,12$ \\
\hline 12 & $1.34(3 \mathrm{H}, \mathrm{d}, 6.3)$ & 11 & $10 \mathrm{~b} / 10 \mathrm{a}, 2 \mathrm{~b} / 2 \mathrm{a}$ & $21.1(\mathrm{q})$ & $9,10,11$ \\
\hline
\end{tabular}

Compound 1 was tested at non-cytotoxic concentrations for antiviral activity against influenza A virus and Herpes simplex virus (HSV) type I. Balticolid was only found to exhibit inhibitory activity against herpes simplex virus with an $\mathrm{IC}_{50}$ value of $0.45 \mu \mathrm{M}$ compared to $0.44 \mu \mathrm{M} /$ aciclovir. The compound showed no remarkable antimicrobial activity against Staphylococcus aureus, Escherichia coli, and Candida maltosa at $200 \mu \mathrm{g}$ /disc in the agar-diffusion assay. Further structural modifications to optimize physico-chemical properties, by total and semi-synthetic approach could result in more 
potent molecules with desirable pharmacokinetic properties. Thorough structure activity relationship (SAR) studies of balticolid derivatives might result in new drug-lead candidates which can be exploited as future drugs.

Figure 1. Structure of balticolid (1).

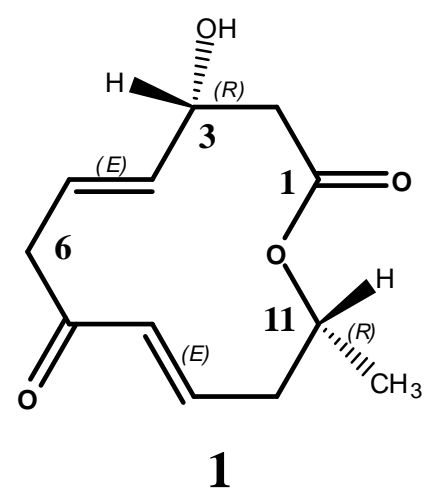

Figure 2. Key NOEs observed for balticolid (1), and their corresponding interatomic distances $(\AA)$.

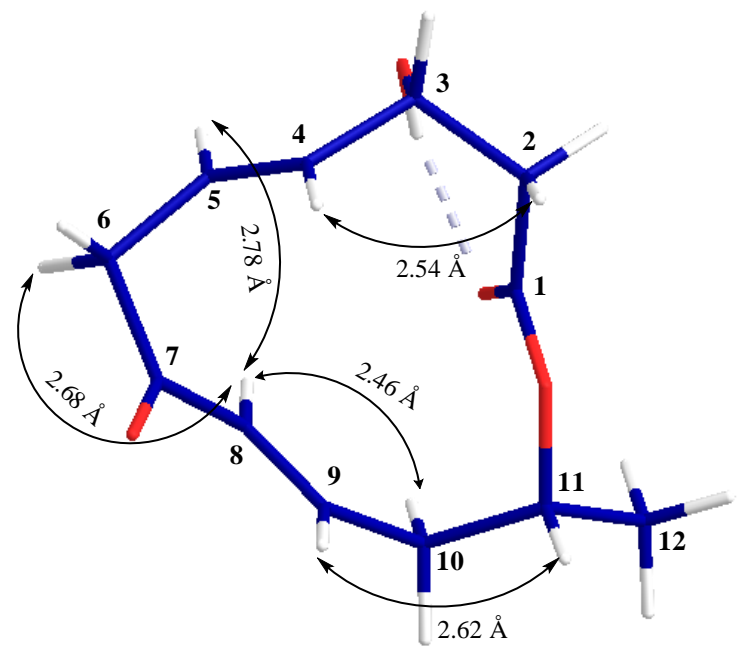

Figure 3. Key ${ }^{1} \mathrm{H}$ NMR chemical shift differences $\Delta \delta\left(\delta_{S}-\delta_{R}\right)$ in ppm for the MTPA esters of $\mathbf{1}$.

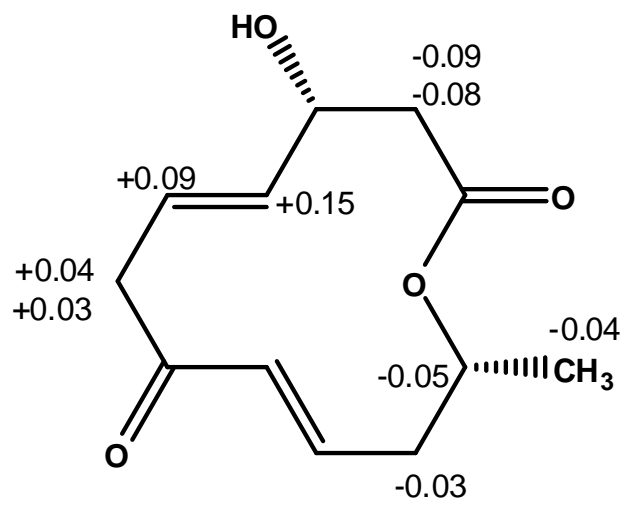




\section{Experimental Section}

\subsection{General Experimental Procedures}

TLC: silica gel $60 \mathrm{~F}_{254}$ on aluminum foil (Merck); detection under daylight and UV light ( $\lambda=254$ and $366 \mathrm{~nm}$ ), and anisaldehyde $(1 \%$ in a solution of $10 \mathrm{~mL}$ of $\mathrm{AcOH}$ in $10 \mathrm{~mL}$ of a $15 \%$ methanolic $\left.\mathrm{H}_{2} \mathrm{SO}_{4}\right)$. Column Chromatography (CC): System 1: silica gel $(0.063-0.200 \mu \mathrm{m})$, solvent gradient: EtOAc/hexane/MeOH 65:35:5, EtOAc/MeOH 95:5, EtOAc/MeOH 50:50, and MeOH. System 2: silica gel $(0.015-0.040 \mu \mathrm{m})$, solvent gradient: DCM/EtOAc 75:25, and EtOAc. RP-HPLC: $250 \times 4 \mathrm{~mm}$; Waters Xterra-RP-C18, $5 \mu \mathrm{m}$, gradient $10 \% \mathrm{MeOH}$ to $100 \% \mathrm{MeOH}$ in $15 \mathrm{~min}, 1.0 \mathrm{~mL} / \mathrm{min}$. Optical rotation and UV spectra were measured in UV MeOH [Uvasol (Merck)] on a Polarimeter MC 241 (Perkin Elmer) and a UV-2102 PC UV-VIS scanning spectrophotometer, respectively in $\mathrm{nm} \lambda_{\max }$ $(\log \varepsilon)$. IR spectra were measured on a Nicolet 20 DXB FT-IR spectrometer. For NMR spectroscopy the samples were dissolved in $99.95 \% \mathrm{CD}_{3} \mathrm{OD}$. NMR spectra were recorded at $300 \mathrm{~K}$ on Bruker DPX300, DMX600 NMR spectrometers locked to the major resonance of $\mathrm{CD}_{3} \mathrm{OD}$. Chemical shifts are given relative to the residual solvent signal, $\mathrm{CD}_{3} \mathrm{OD}\left({ }^{1} \mathrm{H}: 3.31 \mathrm{ppm} ;{ }^{13} \mathrm{C}: 49.15 \mathrm{ppm}\right), \delta$ in ppm, $J$ in Hz. MS: HPLC/MS: 1200 Series HPLC system (Agilent) coupled to a DAD-UV detector (Agilent) and an API 2000 (Sciex); in $\mathrm{m} / \mathrm{z}$ (rel.\%); HR-MS: with an ultra-performance LC system (Accela; Thermo-Fisher, Germany) coupled via automated chip-based nanoelectrospray (NanoMate; Advion, UK) to the LTQ-Orbitrap mass spectrometer (Thermo-Fisher).

\subsection{Strain and Fermentation}

The strain 222 was isolated from driftwood collected in November 2002 from the coast of Greifswalder Bodden, Baltic Sea, Germany, by G. Mernitz and B. Cuypers. The material was classified by A. W. A. M. de Cock, Centraalbureau voor Schimmelcultures, Fungal Biodiversity Centre, Utrecht, The Netherlands, and M. Unterseher, University Greifswald, Institute for Botany and Landscape Ecology, Greifswald, Germany, as a member of the order Pleosporales, Ascomycota, by ITS sequence (accession number in the European Nucleotide Archive FR852578). Since the isolate remained sterile in subcultures on different media an exact taxonomic determination was not possible. The culture has been deposited in the culture collection of the Department of Pharmaceutical Biology, University of Greifswald (Voucher number 222). Fermentation was carried out in liquid shake cultures. $500 \mathrm{~mL}$ Erlenmeyer flasks containing $200 \mathrm{~mL}$ of Hagem medium (ammonium succinate $0.5 \mathrm{~g} ; \mathrm{KH}_{2} \mathrm{PO}_{4} 0.5 \mathrm{~g} ; \mathrm{MgSO}_{4} 7 \mathrm{H}_{2} \mathrm{O} 0.5 \mathrm{~g} ; \mathrm{FeCl}_{3}(1 \%) 0.5 \mathrm{~mL}$; glucose $5 \mathrm{~g}$; malt extract $5.0 \mathrm{~g}$; aqua purificata $1000 \mathrm{~mL}, \mathrm{pH} 7.5$ ) were inoculated with a homogenized pre-culture of a mycelial culture of the strain 222 and cultivated on a rotary shaker $(125 \mathrm{rpm})$ for 19 days at room temperature.

\subsection{Extraction and Isolation}

Mycelium and fermentation broth were separated and the culture broth was extracted with EtOAc. The organic layer was dried with anhydrous sodium sulfate and then concentrated in vacuum using a rotary evaporator to give a brown residue $(500 \mathrm{mg}$ from $11 \mathrm{~L}$ of culture broth). The extract was fractionated by $\mathrm{CC}$ (system 1) to yield seven fractions (A-G) according to chemical monitoring by 
TLC. Fraction D (70 mg) was further subjected to CC (system 2) and 8 fractions (D1-D8) were separated through TLC guided fractionation. Fraction D4 was further purified by RP-HPLC to yield $6.5 \mathrm{mg}$ of balticolid (1).

\subsection{Balticolid (1)}

Colorless oil, $[\alpha]_{D}^{22}+135.2(\mathrm{c}=0.35, \mathrm{MeOH})$; TLC EtOAc:DCM $(3: 1) \mathrm{R}_{\mathrm{f}}=0.3$ (yellow spot after spraying with anisaldehyde/ $\mathrm{H}_{2} \mathrm{SO}_{4}$ reagent and heating); HPLC UV detection at $216 \mathrm{~nm}$, $\mathrm{R}_{\mathrm{t}}=12.2$ min.; UV in MeOH $\lambda_{\max }(\log \varepsilon) 214$ (5456/3.736); IR (KBr) $v_{\max } 3435,1715,1662,1170$, $980 \mathrm{~cm}^{-1}$; HPLC-ESI-MS (ammonium acetate buffer): + ESI $\mathrm{m} / z, 225[\mathrm{M}+\mathrm{H}]^{+}, 242\left[\mathrm{M}+\mathrm{NH}_{4}\right]^{+}, 247$ $[\mathrm{M}+\mathrm{Na}]^{+}$and $470[2 \mathrm{M}+\mathrm{Na}]^{+}$; -ESI m/z $223[\mathrm{M}-\mathrm{H}]^{-}$. HR-(+)-ESI-MS: 471.2001, calcd. 471.1995 for $\mathrm{C}_{24} \mathrm{H}_{32} \mathrm{O}_{8} \mathrm{Na}$ as $[2 \mathrm{M}+\mathrm{Na}]^{+}$.

\subsection{Preparation of (S)- and (R)-MTPA Esters of Balticolid (1)}

Two portions (1.5 mg each) of $\mathbf{1}$ were dissolved in dry $\mathrm{CH}_{2} \mathrm{Cl}_{2}(1 \mathrm{~mL})$ containing $1 \mathrm{mg}$ of dimethylaminopyridine and eight equivalents of dicyclohexylcarbodiimide. Six equivalents of either the $(S)$ or the $(R)$ isomer of $\alpha$-methoxy- $\alpha$-trifluoromethylphenylacetyl chloride were added to a portion of 1 . The reaction mixtures were allowed to stand for $24 \mathrm{~h}$ at room temperature. The reaction was quenched by addition of $1.0 \mathrm{~mL}$ of water, and the mixture was subsequently extracted with $\mathrm{Et}_{2} \mathrm{O}$ $(3 \times 1.0 \mathrm{~mL})$. The $\mathrm{Et}_{2} \mathrm{O}$ soluble layers were combined, dried over anhydrous $\mathrm{MgSO}_{4}$ and evaporated. The residue was subjected to column chromatography over silica gel using $n$-hexane-EtOAc $(13: 1)$ to yield the $(S)$-MTPA and $(R)$-MTPA esters. The key ${ }^{1} \mathrm{H}$ NMR chemical shift differences $\Delta \delta\left(\delta_{S}-\delta_{R}\right)$ in ppm for the MTPA esters of $\mathbf{1}$ are shown in Figure 3.

\subsection{Biological Activities}

An agar diffusion assay according to the European Pharmacopoeia [12] was used to determine antibacterial and antifungal activity. Ampicillin was used as positive control. The following test strains were used: Staphylococcus aureus ATCC 6538, Escherichia coli ATCC 11229, and Candida maltosa SBUG 700. The compound was tested for antiviral activity against influenza A virus and Herpes simplex virus (HSV) type I using a test system as described by Shushni et al. [4]. Briefly, the virus-host systems influenza A virus-Madine-darby canine kidney (MDCK) cells and Herpes simplex virus-African green monkey kidney (Vero) cells were used. Confluent monolayers of the cells were pre-incubated treated with different concentrations of balticolid or reference compounds amantadine and acyclovir in four replicates for $30 \mathrm{~min}$ at $37^{\circ} \mathrm{C}$. MDCK cells were infected with $30 \mathrm{TCID}_{50}$ (tissue culture infectious dose leading to virus infection of $50 \%$ of the cells) of influenza virus $\mathrm{A}$ and Vero cells with $30 \mathrm{TCID}_{50}$ of HSV-I and further incubated for $72 \mathrm{~h}$ at $37{ }^{\circ} \mathrm{C}$. The antiviral effect of test compounds was determined by neutral red assay in comparison to infected cells without test compound and non infected cells. Before antiviral tests a possible cytotoxicity of balticolid for MDCK and Vero cells was measured also by the neutral red assay. Only non-cytotoxic concentrations were used for the antiviral tests. 


\section{Acknowledgements}

The authors thank M. Unterseher and A.W.A.M. de Cock for taxonomic investigation and R. Jansen, Helmholtz Centre for Infection Research, Braunschweig, Germany, for support in structure elucidation.

\section{References}

1. Liberra, K.; Lindequist, U. Marine fungi-a prolific resource of biologically active natural products? Pharmazie 1995, 50, 583-588.

2. Shushni, M.A.M. Isolation, Structure Elucidation and Pharmacological Investigation of Bioactive Secondary Metabolites from In Vitro Cultivated Marine Fungi. Ph.D. Dissertation, Ernst Moritz Arndt University: Greifswald, Germany, 2009.

3. Blunt, J.W.; Copp, B.R.; Munro, M.H.G.; Northcote, P.T.; Prinsep, M.R. Marine natural products. Nat. Prod. Rep. 2011, 28, 196-268.

4. Shushni, M.A.M.; Mentel, R.; Lindequist, U.; Jansen, R. Balticols A-F, new naphthalenone derivatives with antiviral activity, from an ascomycetous fungus. Chem. Biodiversity 2009, 6, 127-137.

5. Vesonder, R.F.; Stodola, F.H.; Wickerham, L.J.; Ellis, J.J.; Rohwedder, W.K. 11-hydroxy-trans-8dodecenoic acid lactone, a 12-membered-ring compound from a fungus. Can. J. Chem. 1971, 49, 2029-2032.

6. Hirota, A.; Sakai, H.; Isogai, A. New plant regulators, cladospolide A and B, macrolides produced by Cladosporium cladosporioides. Agric. Biol. Chem. 1985, 49, 731-735.

7. Fuji, Y.; Fukuda, A.; Hamasaki, T.; Ichimoto, I.; Nakajima, H. Twelve-membered lactones produced by Cladosporium tenuissimum and the plant growth retardarnt activity of cladospolide B. Phytochemistry 1995, 40, 1443-1446.

8. Sekiguchi, J.; Kuroda, H.; Yamada, Y.; Okada, H. Structure of patulolide A, a new macrolide from Penicillium urticae mutants. Tetrahedron Lett. 1985, 26, 2341-2342.

9. Odphaya, D.; Sekiguchi, J.; Yamada, Y. New macrolides from Penicillium urticae mutant S11R59. J. Antibiot. 1986, 39, 629-635.

10. Jadulco, R.; Proksch, P.; Wray, V.; Sudarsono; Berg, A.; Grafe, U. New macrolides and furan carboxylic acid derivative from the sponge-derived fungus Cladosporium herbarum. J. Nat. Prod. 2001, 64, 527-530.

11. Jiao, P.; Swenson, D.C.; Gloer, J.B.; Wicklow, D.T. Chloriolide, a 12-Membered Macrolide from Chloridium virescens var chlamydosporum (NRRL 37636). J. Nat. Prod. 2006, 69, 636-639.

12. Dale, J.A.; Mosher, H.S. Nuclear magnetic resonance enantiomer reagents. Configurational correlations via nuclear magnetic resonance chemical shifts of diastereomeric mandelate, o-methylmandelate, and a-methoxy-a-trifluoromethylphenylacetate (MTPA) esters. J. Am. Chem. Soc. 1973, 95, 512-519.

13. Ohtani, I.; Kusumi, T.; Kashman, Y.; Kakisawa H. Highfield FT NMR application of Mosher's method. The absolute configurations of marine terpenoids. J. Am. Chem. Soc. 1991, 113, 4092-4096. 
14. Hoye, T.R.; Jeffrey, C.S.; Shao F. Mosher ester analysis for the determination of absolute configuration of stereogenic (Chiral) carbinol carbons. Nat. Protoc. 2007, 2, 2451-2458.

15. European Pharmacopoea, 4th ed.; Council of Europe: Strasbourg, France, 2001; Section 2.7.2, pp. 160-161.

(C) 2011 by the authors; licensee MDPI, Basel, Switzerland. This article is an open access article distributed under the terms and conditions of the Creative Commons Attribution license (http://creativecommons.org/licenses/by/3.0/). 